\title{
PELAYANAN KESEHATAN TAHANAN PADA KONDISI OVER CROWDED DI RUMAH TAHANAN NEGARA KLAS 1 CIPINANG
}

\author{
Dini Ramayani \\ Politeknik Ilmu Pemasyarakatan, Manajemen Pemasyarakatan. Jl. Raya Gandul No.4 Gandul, \\ Kecamatan Cinere, Kota Depok, Jawa Barat, 16514, Indonesia \\ E-mail: diniramadanni98@gmailcom
}

\section{DETAINEES HEALTH SERVICES IN OVER CROWDED CONDITION IN CIPINANG CLASS 1 STATE DETENTION}

\begin{abstract}
With an overcrowded Penitentiary condition, basically health services for prisoners in the Penitentiary and State Detention Centers are not maximal when the number of prisoners and detainees exceeds the capacity limit, in this case an inadequate condition of facilities and infrastructure is found, but with an inhibiting factor in the health service process. such as: lack of nutrition and calorie intake, but also with health problems for prisoners and detainees. Dense occupancy rates of prisons and remand centers prevent detention and prisons in carrying out the functions of poor health services, even in addition to excessive occupancy rates (over capacity) has an impact on the death rate of prisoners. The purpose of this research itself is to determine the health service effort that can be done in order to deal with Over Crowded problems that exist in Cipinang Class 1 State Detention Center, this research was conducted using qualitative descriptive research supported by field research in the form of interviews with information. And the results of this study concluded that there were obstacles in the shortage of medical equipment and drugs the imbalance of the number of medical personnel with prisoners.
\end{abstract}

Keywords: Health, Penitentiary, State Detention Center, Prisoners

\begin{abstract}
Abstrak
Dengan kondisi Lembaga Pemasyarakatan yang Over Kapasitas pada dasarnya pelayanan kesehatan pada narapidana di Lembaga Pemasyarakatan maupun Rumah Tahanan Negara tidaklah maksimal manakala jumlah narapidana dan tahanan melebihi batas tampung dalam hal ini ditemukanya kondisi sarana dan prasarana yang tidak memadai melainkan dengan adanya faktor penghambat dalam proses pelayana kesehatan seperti minimnya asupan gizi dan kalori, juga melainkan dengan gangguan kesehatan bagi narapidana dna tahanan. Padatnya tingkat hunian Lapas maupun Rutan menghambat Rutan maupun Lapas dalam melaksanakan fungsi dari pelayanan kesehatan yang tidak baik, bahkan disamping tingkat hunian yang berlebih ( Over kapasitas ) berdampak pada tingkat kematian narapidana. Tujuan dari penelitian ini sendiri untuk menentukan upaya pelayanan kesehatan yang dapat dilakukan dalam rangka menangani permasalahan Over Crowded yang ada pada Rumah Tahanan Negara Kelas 1 Cipinang, penelitian ini dilakukan menggunakan penelitian deskriptif kualitatif yang didukung oleh penelitian lapangan dengan bentuk wawancara dengan infroman. Dan hasil dari penelitian ini diperoleh kesimpulan bahwa ditemukan kendala dalam kekurangan peralatan medis dan obat-obatan tidak seimbangnya jumlah tenaga medis dengan tahanan.
\end{abstract}

Kata Kunci : Kesehatan, Lembaga Pemasyarakatan, Rumah Tahanan Negara, Narapidana 


\section{PENDAHULUAN}

Manusia adalah makhluk tuhan yang sangat mulia dan mempunyai drajat yang luhur dimata tuhan yang maha kuasa. Setiap manusia mempunyai martabat dan tingkatan yang sama, dan memiliki hak-hak yang sama pula. Setiap manusia bebas mengembangkan diri sesuai dengan budinya yang sehat sebagai makhluk ciptaan tuhan yang maha kuasa. Hak yang sama sebagai insan manusia inilah yang disebut dengan Hak Asasi Manusia (HAM). Hak asasi manusia adalah hak-hak yang melekat berdasarkan kodratnya sebagai manusia sejak iya dilahirkan dan tidak boleh seorang pun yang dapat mengambil hak tersebut dengan sewenangwenang ${ }^{2}$ telah tertuang dengan jelas secara eksplisit bahwa setiap orang berhak mendapatkan lingkungan yang sehat dan memperoleh hak yang sama dalam pelayanan kesehatan bagi pencapaian derajat kesehatan. Dalam pasal 14 ayat (1) Undang-Undang Nomor 12 Tahun 1995 dijelaskan tentang hak-hak narapidana yang dimana pada point (d) disebutkan bahwa narapidana berhak mendapatkan pelayanan kesehatan pada dasarnya menyangkut semua aspek kehidupan masyarakat dan berlangsung pada setiap individu, tidak terkecuali bagi mereka yang sedang menjalani hukumanya di dalam Lembaga Pemasyarakatan dan Rumah
Tahanan Negara. Trend meningkatnya jumlah penghuni pada Lembaga Pemasyarakatan (Lapas) atau Rumah Tahanan Negara (Rutan) sudah dimulai sejak era tahun 90an, seiring dengan berkembangnya narkoba di Indonesia. Hingga kini, hampir seperempat abad lamanya persoalan Over Crowded di Lapas maupun Rutan masih menjadi persoalan panjang bagi Kementerian Hukum dan Hak Asasi Manusia (HAM) khususnya Direktorat Jenderal Pemasyarakatan. ${ }^{1}$

Meningkatnya kejahatan, baik secara kualitas maupun kuantitas, telah berpengaruh terhadap pelaksanaan tugas pemasyarakatan. Sekarang, perilaku juga tindakan kejahatan tidak hanya melibatkan pelaku dari kalangan tidak berpendidikan atau kalangan ekonomi lemah. Perilaku kejahatan telah melibatkan pelaku-pelaku yang mempunyai latar belakang pendidikan tinggi, birokrat, bahkan pejabat negara kondisi demikian sangat bepengaruh terhadap tata kehidupan di dalam Rutan. Berdasarkan data resmi Direktorat Jenderal Pemasyarakatan melalui situs resmi smslap.ditjenpas.go.id, jumlah narapidana di Lapas maupun Rutan pada bulan Januari Tahun 2020 meningkat menjadi 265.868 penghuni dengan tingkat Over Crowded sebesar $102 \%$. Persoalan ledakan jumlah penghuni di Lapas dan Rutan sudah 
mengemukakan seiring dengan maraknya peredaran narkoba di Indonesia berbagai cara dan upaya telah dilakukan Direktorat Jenderal Pemasyarakatan Kementerian Hukum dan Ham untuk meredakan lonjakan peningkatan jumlah penghuni tersebut. Berdasarkan data sistem database pemasyarakatan hamper seluruh unit pelaksana teknis (UPT) di Kanwil DKI Jakarta mengalami kondisi Over Crowded Rutan Kelas 1 Cipinang meupakan salah satu rutan dengan tingkat Over Crowded yang tinggi di Kantor Wilayah DKI Jakarta yaitu sebesar $271 \%$ atau sebanyak 4.211 penghuni dengan kapasitas seharusnya 1.136 penghuni. Hal ini harus menjadi perhatian khusus karena dapat tingkat Over Crowded yang tinggi akan menimbulkan berbagai permasalahan-permasalahan didalam Lapas dan Rutan.

Berbagai permasalahan yang terjadi akibat Over Crowded yang terjadi pada Rumah Tahanan Negara Kelas 1 Cipinang yaitu dari permasalahan perkelahian antar penghuni, penyerangan terhadap petugas pengamanan Rutan, pelarian, penyelundupan narkoba, serta pelayanan kesehatan yang tidak merata. Salah satu dampak serius yang dapat dirasakan oleh penghuni Rutan adalah memburuknya kondisi kesehatan para penghuni akibat kepadatan yang terjadi didalam kamar hunian Rutan. Selain itu kondisi Over Crowded didalam Rutan klas 1 cipinang juga membuka peluang semakin meluasnya berbagai penyakit menular seperti TBC bahkan HIV/AIDS.

Pelayanan kesehatan bagi narapidana atau tahanan dilaksanakan berdasarkan Undang-Undang No. 12 Tahun 1995 tentang pemasyarakatan dan Undang-Undang Nomor 36 Tahun 2009 tentang kesehatan. Sebagai bagian dari pelayanan kesehatan yang bersifat di masing-masing UPT Lapas dan Ruta, setiap narapidana berhak untuk mendapatkan kesehatan yang layak. Layanan ini diberikan kepada narapidana yang membutuhkan tindakan medis terkait dengan kondisi kesehatanya selama di UPT Lapas dan Rutan. Padatnya tingkat hunian Rutan maupun Lapas menghambat Rutan maupun Lapas dalam melaksanakan fungsi pelayanan atau pembinaan, bahkan tingkat hunian yang berlebih (Overkapasitas) dapat mengakibatkan tingginya tingkat kematian narapidana ${ }^{3}$.

Kelebihan kapasitas yang tidak sebanding dengan luas dan hunian akan berakibat sangat cepat narapidana dan tahanan terjangkit penyakit menular (pusat pengkajian dan pengembangan kebijakan departemen hukum dan ham dindin sudiman, 2007). 
Sesuai dengan latar belakang permasalahan yang ada, maka penulis mencoba mengambil perumusan masalah sebagai berikut : Tentang dampak dan pelayanan kondisi Over Crowded terhadap kesehatan tahanan di Rumah Tahanan Negara Klas 1 Cipinang Keberhasilan pemasyarakatan narapidana tidak terlepas dari sarana yang tersedia. Dalam hal ini sarana yang dimaksud pun harus mengacu kepada The Standar Minimum Of Rules For The Treatment Of Prisoners, 31 juli 1957. Kamar tidur ataupun kamar berventilasi, air serta lampu penerang kamar, makanan yang bersih dan sehat, sarana kesehatan seperti Rumah Sakit, Fasilitas olah raga. Semua itu untuk mendukung jalanya pembinaan. Oleh karena itu ketersediaan sarana ini menjadi salah satu ukuran pemasyarakatan(Petrus Irwan pandjaitan dan Wiwik Sri Widiarty, 2008).

\section{BAHAN DAN METODE}

Penelitian merupakan serangkaian kegiatan ilmiah dalam rangka pemecahan suatu permasalahan(azwar s, 2010), pada penelitian yang akan peneliti lakukan dengan permasalahan yang akan diteliti. Pada penelitian ini menggunakan metode penelitian kualitatif. Untuk mengetahui dan mengidentifikasi seperti pada judul “ Pelayanan Kesehatan Tahanan Pada Kondisi
Over Crowded Di Rumah Tahanan Negara klas 1 Cipinang" dengan judul tersebut pada pengambilan data secara langsung maka peneliti dalam hal ini menggunakan jenis penelitian deskriptif dengan tujuan mendapatkan infoormasi tentang gambaran mengenai peran Rumah Tahanan Negara Klas 1 Cipinang.

Jenis penelitian ini yang digunakan adalah mengumpulkan data dari para informan dan melalui dokumen yang sesuai dengan penelitian ini. Teknik yang digunakan adalah data primer dan data skunder yang dilakukan dengan wawancara dan observasi lapangan, kemudian pada data sekunder yaitu melalui studi kepustakaan dengan dokumen-dokumen penting yang terlibat dalam penelitian ini. Penelitian ini berlokasi pada Unit Pelaksana Teknis Pemasyarakatan pada Rumah Tahanan Negara Klas 1 Cipinang pada akhir bulan Februari 2020, pada populasi penelitian adalah seluruh pegawai di Rumah Tahanan Negara Klas 1 Cipinang dan sampel penelitian adalah pegawai dibidang staf KPR dan pegawai poliklinik.

Dalam penelitian ini, penulis melakukan pengumpulan data dengan cara melakukan wawancara kepada beberapa responden serta melalui pengamatan atau 
observasi terhadap keadaan dan kondisi yang terjadi dilapangan yaitu Rumah Tahanan Negara Klas 1 Cipinang. Pada pengamatan ini peneliti mengamati muali dari kondisi Rumah Tahanan Negara Kelas 1 Cipinang secara keseluruhan dan setelah itu dimulai berfokus pada bidang pelayanan kesehatan yaitu pada kesehatan tahanan. Setelah itu peneliti menentukan narasumber yang akan diwawancarai, disini peneliti mewawancarai adalah yang memiliki hubungan atau berkaitan dengan masalah yang peneliti teliti yaitu Kepala Seksi Pelayanan Tahanan, Dokter Poliklinik, dan beberapa Tahanan, Untuk melakukan analisa data, peneliti menangkap, mencatat, menginterprestasikan dan menyajikan informasi.

\section{HASIL}

\section{0 penyakit terbanyak Berdasarkan pasien Berobat Klinik Pratama Rutan Klas I Cipinang Tahun 2020}

\section{Tahun 2020}

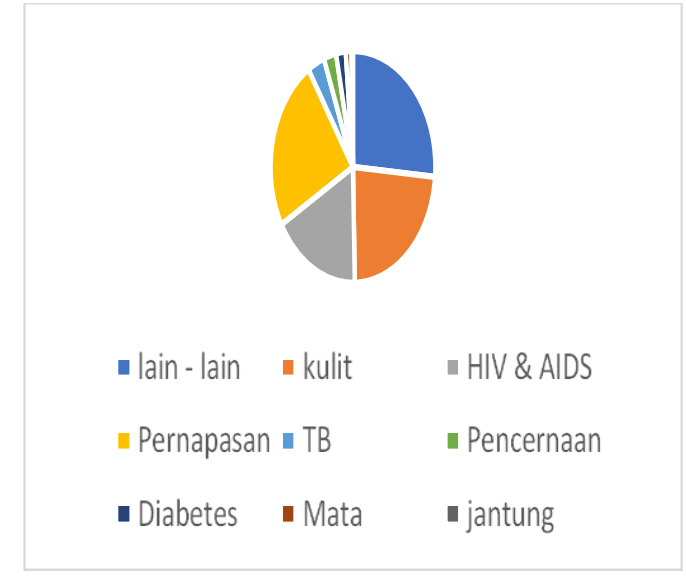

Gambar 1.1

Dari data diatas dapat disimpulkan bahwa ada 1.888 pasien yang mengidap penyakit kulit, pernafasan sebanyak 1.962 pasien, HIV sebanyak 1.286 pasien, TB sebanyak 270 pasien. Pencernaan sebanyak 198 pasien, diabetes sebanyak 155 pasien, sakit mata sebanyak 91 pasien, sakit jantung sebanyak 23 pasien, dan penyakit lainya berjumlah 2.140 orang. Kondisi Poliklinik Pratama telah didirikan bersamaan dengan Pembangunan Rutan Cipinang, Poliklinik Pratama dilengkapi dengan obat-obatan, satu ruang gigi, satu ruang poli umum, satu ruang opname yang 
terdiri dari 6 tempat tidur dalam satu ruangan. Poliklinik pratama dibantu oleh 6 dokter yang bertugas di Rutan Cipinang. Dengan peralatan dokter gigi yang memadahi mampu melayani kesehatan Tahanan dalam menangani permasalahan sakit gigi yang diderita tahanan. Ruang opname yang tersedia di Rumah Tahanan Negara Klas 1 Cipinang mampu menampung 6 orang pasien rawat inap. selama dalam melaksanakan proses penelitian di Rumah Tahanan Negara Klas 1 Cipinang ada beberapa hal yang penulis temukan, temuan tersebut penulis dapat ketika melakukan observasi maupun wawancara baik kepada petugas, narapidana, maupun tahanan. Beberapa temuan seperti :

\section{1) Tenaga Medis dan Paramedis}

Berdasarkan data yang diambil dari Seksi Pelayanan Tahanan pada tanggal 18 Februari 2020, Rumah Tahanan Klas 1 Cipinang memiliki tenaga medis dan paramedis berjumlah 12 orang yaitu, 4 orang dokter umum dan 2 orang dokter gigi, serta 6 perawat. Tenaga medis dan paramedis ini disediakan oleh Kementerian
Hukum dan Hak Asasi Manusia namun tidak bisa stanby selama 24jam, karena keterbatasan tenaga dan beberapa orang tempat tinggalnya jauh dari Rutan. Dalam pelaksanaanya pelayanan kesehatan tenaga medis dan paramedis Rumah Tahanan Negara Klas 1 Cipinang melayani 42 pasien tiap harinya, jumlah ini tidak sebanding dengan tenaga medis dan paramedis yang ada di dalam Rumah Tahanan Negara Klas 1 Cipinang. Menurut koordinator dokter Rutan Cipinang mengatakan bahwa: “ memang kita disini kekurangan tenaga medis, kita hanya punya 6 orang tenaga, seharusnya minimal kita punya 10 orang tenaga medis jika kit lihat dari narapidana dan tahanan yang mencapai 4300 orang lebih, jadi yaa sering kali kita kewalahan menanganinya, walaupun kita di Rutan Klas 1 dan ibukota negara tapi gak jadi jaminan medis kita lengkap. Seharusnya 1 orang dokter hanya bisa melayani maksimal 30 pasien perhari agar lebih efektif'( berdasarkan wawancara dengan dr.Yulius N Sumarli, koordinator dokter Rutan Cipinang, 17 februari 2020 ) 
Table 1.2

Data Pasien Di Rutan Dari Januari- Februari 2020

Sumber : seksi pelayanan

\begin{tabular}{|c|c|c|}
\hline \multirow[t]{2}{*}{ Jumlah pasien } & \multicolumn{2}{|c|}{ TAHUN 2020} \\
\hline & Januari & Februari \\
\hline Meninggal & 0 & 0 \\
\hline Rawat jalan & 120 & 218 \\
\hline Rawat Inap & 1 & 19 \\
\hline \multirow[t]{2}{*}{ Rawat luar } & 14 & 10 \\
\hline & 135 & 258 \\
\hline Jumlah & & 778 orang \\
\hline
\end{tabular}

Dari data yang didapat dari seksi pelayanan tahanan Rumah Tahanan Negara Klas 1 Cipinang rata-rata setiap bulanya petugas medis melayani 255 orang narapidana dan tahanan yang mengalami gangguan kesehatan sehingga 6 orang tenaga dokter harus melayani 42 orang tiap harinya. Oleh karena itu dalam pelaksanaan pelayanan kesehatan petugas medis di bantu dengan tamping dan tidak jarang pula tamping tersebut melakukan tindakan medis pada saat petugas medis sedang tidak berada ditempat karena keperluan tertentu misalnya cuti dan sebagainya.

\section{2) Kondisi sarana dan prasarana poliklinik pratama}

Pada data dengan keadaan beberapa perlengkapan yang rusak sehingga proses pelayanan bagi tahanan yang sangat banyak belum dapat berjalan dengan optimal terutama pada kondisi rawan penyakit seperti pada saat cuaca yang berubah-ubah. Untuk kasus-kasus yang berat akan ditangani oleh pihak Rumah sakit pengayoman melalui prosedur yang telah ada sesuai dengan peraturan. Menurut keterangan dokter poliklinik mengatakan bahwa : “, ,. yah beginilah adanya keadaan poliklinik kita, walaupun UPT di Jakarta dan Rumah Tahanan Negara Klas 1 Cipinang tapi peralatan kita sangat seadanya, jadi yaa kami melayani pasien 
dengan seadanya. Seharusnya peralatan medis harus lengkap contoh : tensi meter, dan tabung oksigen juga alat bantu nafas harus baik, tapi kenyataanya .." (berdasarkan wawancara dengan Vera, selaku dokter umum Rutan, tanggal 17 februari 2020). Pernyataan tersebut mengisyaratkan bahwa peralatan medis masih kurang memadai dikarenakan beberapa peralatan medis dan rusak tidak layak. Hal ini yang menjadi penghambat dalam layanan kesehatan, sehingga layanan kesehatan dilakukan dengan seadanya.

Dari data yang didapat dari hasil wawancara dan observasi lapangan menunjukan bahwa adanya ketidak seimbangan antara jumlah petugas kesehatan dengan jumlah tahanan yang ada di Rumah Tahanan Negara Klas 1 Cipinang, dan ditambah dengan peralatan medis yang kurang memadai sehingga dalam pelaksanaan pelayanan kesehatan kurang optimal. Jika ditinjau dengan teori Service Quality oleh Zeithnal, yang mengatakan bahwa pelayanan disebut berkualitas apabila pelayanan yang diterima relative lebih memuaskan dilihat dari sudut pandang pelanggan, sudut pandang tersebut antara lain : a. Tangible : yaitu bukti yang ditujukan oleh fasilitas fisik, peralatan yang digunakan, penampilan karyawan, material, dan sarana komunikasi

b. Reliability : menyajikan jasa sesuai dengan janji dengan akurat dan memuaskan

c. Responsivines : kesediaan para karyawan untuk membantu pelanggan dan menyajikan pelayanan dengan segera

d. Assurance : pengetahuan, keterampilan, dan kemampuan serta sopan santun petugas dan memberikan pelayanan, aman dari bahaya, resiko, keraguan serta memiliki sifat dapat dipercaya

e. Emphaty : kemudahan dalam berinteraksi, komunikasi yang baik, memberikan pehatian secara pribadi serta memahami kebutuhan dan keinginan pelanggan.(Zeithaml, 2009)

Maka dapat disimpulkan bahwa kualitas pelayanan kesehatan di Rumah Tahanan Negara Klas 1 Cipinang belum sepenuhnya optimal, dikarenakan masih adanya kekurangan seperti peralatan yang kurang memadai, obat-obatan yang kurang serta jumlah personil petugas medis yang tidak sebanding dengan jumlah narapidana dan tahanan. Untuk itu diperlukan adanya inovasi dalam mengatasi permasalahan 
tersebut dengan cara membuat layanan kesehatan berbasis teknologi informasi dan komunikasi guna pemenuhan hak narapidana dan tahanan agar dapat berjalan

\section{PEMBAHASAN}

Berdasarkan data yang diperoleh pada observasi lapangan, salah satu yang menjadi faktor utama penyebab terjadinya Over Crowded adalah adanya ketidak seimbangan perbandingan antara narapidana yang masuk (bertambah) dengan narapidana yang keluar (berkurang) walaupun rata-rata setiap hari terdapat berkurangnya narapidana. Semakin banyaknya tindak kriminalitas akan menjadi salah satu penyebab terjadinya Over Crowded.

Di seluruh wilayah Indonesia, Rumah Tahanan Negara cenderung memiliki masalah dalam Pleayanan kesehatan tahanan, masalah yang kian terjadi pada Rumah Tahanan Negara adalah terjadinya Over Crowded. Besarnya jumlah yang terjadi akibat kejahatan yang kian marak dan semakin tingginya tingkat kejahatan. Tingginya angka kejahatan mengakibatkan besarnya jumlah tahanan maupun narapidana pada Rumah Tahanan Negara dan ini akan berdampak pada kesehatan masing-masing tahanan. Dalam hal ini Over dengan optimal dan diharapkan dapat di implementasikan di Lapas/Rutan di seluruh Indonesia.

Crowded di Rumah Tahanan Negara Klas 1 Cipinang akan membahayakan kesehatan dari narapidana dan tahanan yang dapat menyebabkan kematian. Berdasarkan pada lampiran Keputusan Direktur Jenderal Pemasyarakatan Nomor : PAS-14.OT.02.02 Tahun 2014 tentang standar pelayanan pemasyarakatan, berikut ini adalah jenis layanan publik di UPT pemasyarakatan khususnya di Lapas/Rutan yang telah

ditetapkan dalam peraturan bidang kesehatan narapidana dan tahanan. Pelayanan kesehatan dilaksanakan menurut Undang-Undang Nomor 36 Tahun 2009 tentang kesehatan. Sebagai bagian dari pelayanan kesehatan yang bersifat mandat di masing-masing Lapas/Rutan. Setiap narapidana dan tahanan berhak mendapatkan layanan kesehatan yang layak. Layanan inni diberikan untuk narapidana atau tahanan berupa tindakan medis terkait dengan kondisi kesehatanya selama di Lapas/Rutan. Dan setiap Lapas/Rutan setidaknya harus menyediakan poliklinik beserta fasilitasnya. Layanan 
kesehatan ini diberikan bagi narapidana dalam bentuk pencegahan maupun pengobatan. Pencegahan dilakukan guna meminimalisir tersebarnya penyakit didalam Lapas/Rutan. Sedangkan pengobatan merupakan upaya untuk memberikan kesehatan bagi narapidana yang sedang menderita sakit agar program pembinaan dapat berjalan dengan optimal.“ bahwa beberapa faktor yang menyebabkan tingginya angka kesakitan, penyakit bersumber dari lingkungan organisme di Rutan Klas 1 Cipinang antara lain keadaan Over Crowded penyebab kepadatan, perilaku penghuni yang buruk ditambah lagi adanya perubahan iklim dan keadaan lingkungan serta sanitasi yang buruk. Sesuai laporan riskedas bulan lalu, masalah yang menyulitkan pengendalian

Vektor di Lapas antara lain prningkatan populasi resisten beberapa vektor terhadap keadaan rutan, keterbatasan dan ketidakseriusan beberapa anggota atau petugas Rutan untuk mengawasi perilaku kebersihan penghuni Rutan serta biaya operasional yang terbatas untuk penanggulangan vektor penyakit menular dan belum adanya kerja sama dengan dinas kesehatan tentang pengendalian vektor secara berkala" (wawancara dengan Karutan Klas 1 Cipinang Ulin Nuhha, A.MD.IP.,S.Sos,S.H.,M.si 18 februari 2020)

1. Faktor penyebab kurangnya pelayanan kesehatan di Poliklinik

Gambaran bahwa masalah Over Crowded di Rumah Tahanan Negara Klas 1 Cipinang mempunyai dampak terhadap kesehatan tahanan di Rutan. Sejalan dengan terobosan yang dilakukan Rumah Tahanan Negara Klas 1 Cipinang berupaya mengoptimalkan pelayanan kesehatan tahanan dapat menyeluruh untuk semua tahanan dan narapidana untuk meminimalisir penyakit yang dirasakan oleh tahanan dan narapidana dalam situasi rutan yang mengalami Over Crowded, namun dalam pelaksanaanya ditemui beberapa permasalahan yaitu:

Dari aspek tenaga medis, hal yang menonjol adalah kekurangan petugas medis dari Rutan Cipinang melakukan penanggulangan skait yang diderita tahanan.

"saya pernah jatuh dari tangga blok hunian pada saat malam hari ketika akan mengambil air minum, ketika itu kaki saya terkilir dan mengalami luka cukup serius tetapi ketika saya dibawa ke poliklinik dokter yang berada di poliklinik tidak berada ditempat sehingga saya harus 
menunggu beberapa jam untuk mendapatkan tindakan medis dari tamping poliklinik" (wawancara dengan tahanan blok narapidana tindak pidana umum, pada tanggal 20 februari 2020).

Dari sarana medis seperti obat-obatan hal yang menonjol adalah kekurangan obatoabatan sehingga tahanan mengalami sakit yang diderita tidak mengalami kesembuhan.

\section{Analisa pemecahan masalah}

Dari aspek tenaga medis, berkaitan dengan respon dokter yang kurang dan tenaga yang kurang handal dalam bidangnya. Dalam menghadapi rutan yang mengalami kondisi Over Crowded merupakan suatu tantangan besar yang dihadapi Poliklinik di Rutan. Penambahan tenaga medis agar berlangsungnya kegiatan pelayanan kesehatan di poliklinik dapat terlaksana dengan baik dalam menghadapi kondisi rutan yang Over Crowded. Spesifikasi dari tenaga medis juga diperlukan untuk menguasai bidang medis yang dibutuhkan Rutan.

Dari aspek sarana medis yang ada di poliklinik Rutan Klas 1 Cipinang, masih perlu adanya pengadaan obat yang lengkap serta alat-alat medis yang digunakan dalam pelayanan kesehatan agar tidak terjadi penularan penyakit yang berkepanjangan didalam Rutan Klas 1 Cipinang.

\section{Teknik pemeriksaan data keabsahan data}

Teknik pengumpulan data yang digunakan untuk melengkapi dalam memperoleh data primer dan sekunder, observasi dan interview digunakan untuk menjaring data primer yang berkaitan dengan pelaksanaan kesehatan di Rumah Tahanan Negara Klas 1 Cipinang, sementara studi dokumentasi digunakan untuk menjaring data sekunder yang dapat diangkat dari berbagai dari wawancara dan data. Berikutr dijelaskan keabsahan temuan-temuan penelitian :

a) Credibility (derajat kepercayaan ataui validitas internal ) Tujuanya untuk menggambarkan kecocokan konsep peneliti dengan konsep yang ada pada responden dan narasumber.

b) Transferabilitas (derajat keteralihan) Dalam penelitian ini, transferabilitas digunakan untuk menjamin bahwa hasil penelitian yang diperoleh dapat diterapkan dalam situasi tertentu.

\section{KESIMPULAN}

Berdasarkan analisa permasalahan yang berkaitan dengan pelaksanaan pelayanan kesehatan dalam penegakan Hak Asasi 
Manusia pada Rumah Tahanan Negara Klas 1 Cipinang, maka pada penulis menyimpulkan : Pelayanan kesehatan di Rumah Tahanan Negara Klas 1 Cipinang telah dilakukan sesuai dengan peraturan yang berlak, bakan Kepala Rutan Klas 1 Cipinang telah melakukan terobosan dengan membentuk Tim SOS (tim yang bertugas membantu pelayanan kesehatan tahanan di dalam Rumah Tahanan Negara Klas 1 Cipinang). Dalam pelaksanaan pelayanan kesehatan ditemui kendala antara lain adanya kekurangan peralatan medis dan obat-obatan, tidak seimbangnya jumlah tenaga medis dan paramedis dengan tahanan. Dalam pelaksannan pelayanan kesehatan dan kegiatan administrasi seringnya dilakukan oleh tamping, sehinngga pelayanan kesehatan di Rumah Tahanan Negara Klas 1 Cipinang belum optimal

\section{DAFTAR RUJUKAN}

1. azwar s. (2010). Metode Penelitian. Yogyakarta. pustaka belajar.

2. Petrus Irwan pandjaitan dan Wiwik Sri Widiarty. (2008). pembaharuan pemikiran Dr. saharjo mengenai pemasyarakatan narapidana. CV. Andhill.

3. pusat pengkajian dan pengembangan kebijakan departemen hukum dan ham dindin sudiman. (2007). Reposisi dan Revitalisasi Pemasyarakatan dalam sistem peradilan pidana di Indonesia. CV. Alindra Dunia Perkasa.

4. Republik Indonesia. (2009). undang-undang RI No.36 Tentang Kesehatan.

5. Sumber http://smslap.ditjenpas.go.id/public/grl/current/montly. (n.d.).

6. Zeithaml. (2009). teori service Quality. 